\title{
TRACER STUDY ALUMNI JURUSAN TADRIS ILMU PENGETAHUAN SOSIAL IAIN SYEKH NURJATI CIREBON
}

\author{
Yeti Nurizzati \\ IAIN Syekh Nurjati Cirebon \\ yeti@syekhnurjati.ac.id
}

\begin{abstract}
ABSTRAK
Belum adanya data yang akurat tentang keberadaan lulusan Jurusan Tadris Ilmu Pengetahuan Sosial khususnya dari tahun 2015 hingga tahun 2018, sementara data tentang keberadaan lulusan ini sangat diperlukan khususnya dalam melihat kesesuaian pekerjaan alumni, relevansi kurikulum Jurusan Tadris IPS, dan keberadaan himpunan alumni. Oleh karena itulah diperlukannya riset penelusuran alumni (tracer study) di Jurusan Tadris IPS IAIN Syekh Nurjati Cirebon. Data berasal dari alumni Jurusan Tadris IPS tahun 2015-2019 dengan cara mengisi angket yang tersedia di google form sebanyak 51 responden. Data yang terkumpul kemudian diolah dengan menggunakan statistika deskriptif dan disajikan dalam bentuk tabel dan grafik. Hasil penelitian diperoleh bahwa rata-rata waktu tunggu alumni untuk mendapatkan pekerjaan pertama kali adalah 3,96 bulan dengan rata-rata gaji pertama sebesar Rp 958.000.,- per bulan. Jenis pekerjaan alumni yang pertama sebagian besar sudah sesuai sebagai guru, sisanya sebagai staff swasta, staff pemerintahan dan wirausaha. Lebih dari setengahnya alumni menyatakan bahwa kurikulum Jurusan Tadris IPS cukup sesuai dengan ilmu pengetahuan yang dibutuhkan pekerjaan yaitu ilmu-ilmu sosial, ilmu-ilmu pendidikan, dan ilmu teknologi informasi komunikasi. Saat ini, keberadaan himpunan alumni Jurusan Tadris IPS masih sebatas grup kelas di media sosial. Kegiatan alumni yang sering dilakukan adalah kegiatan keagamaan, bakti sosial, dan pelatihan character building. Melalui kegiatan ini, antar alumni bisa saling silaturahmi, berbagi informasi, diskusi santai dan menambah jaringan.
\end{abstract}

Kata Kunci: Tracer Study, Pekerjaan Alumni, Kurikulum, Himpunan Alumni

\begin{abstract}
There is no accurate data on the existence of graduate majoring in Tadris Social Sciences, especially from 2015 to 2018, while data on the existence of graduates is very necessary, especially in looking at the suitability of graduate work, curriculum relevance at the Tadris IPS Department, and the existence of graduate associations. That is why the need for tracer study of graduate research in the Tadris IPS Department of IAIN Syekh Nurjati Cirebon. The data came from the graduate of the Tadris IPS Department in 2015-2019 by filling out questionnaires available on google forms for 51 respondents. The collected data is then processed using descriptive statistics and presented in tables and graphs. The results showed that the average waiting time for alumni to get a first time job was 3.96 months with an average first salary of Rp. 958,000 per month. The first types of graduate work are mostly suitable as teachers, the rest are private staff, government staff and entrepreneurs. More than half of the graduate stated that the curriculum of the Tadris IPS Department was quite in accordance with the knowledge needed for work, namely the social sciences, education sciences, and communication information technology. At present, the existence of the Tadris IPS Department graduate association is still limited to class groups on social media.
\end{abstract}

Jurnal Edueksos Vol IX, No. 2, Desember 2020

The journal of social and economics education 
Graduate activities that are often carried out are religious activities, social service, and character building training. Through this activity, graduate can get together with each other, share information, have casual discussions and add networks.

Keywords: Tracer Study, Graduate Work, Curriculum, Graduate Association

\section{A. PENDAhuluan}

Kesiapan alumni perguruan tinggi untuk tampil di masyarakat dan aktifitas dunia kerja merupakan salah satu tolak ukur keberhasilan proses pembelajaran yang dilakukan oleh sebuah lembaga pendidikan. Dengan kata lain, keberhasilan pendidikan di sebuah perguruan tinggi tidak semata-mata ditentukan oleh proses belajar mengajar yang dilakukan dan keberadaan fasilitas penunjangnya, tetapi juga harus dilihat dari lulusan yang dihasilkannya. Semakin banyak lulusannya masuk dalam dunia kerja, secara sederhana dapat dinilai bahwa perguruan tinggi tersebut semakin baik kualitasnya.

Seberapa besar lulusan perguruan tinggi mampu berkiprah dalam pembangunan sesuai relevansi pendidikannya dapat dilakukan melalui upaya penelusuran terhadap lulusannya (Tracer Study). Evaluasi terhadap kompetensi yang dibutuhkan oleh dunia kerja sangat diperlukan oleh perguruan tinggi agar tidak terdapat jarak antara dunia pendidikan tinggi dengan dunia kerja yang ada di masyarakat (Chandra \& Ruhama, 2014). Ada beberapa istilah yang memiliki pengertian hampir sama dengan tracer study yaitu graduate survey, alumni research, follow up study, dan labor market signal (Syaubari, Meilina, \& Adisalamun, 2015).

Tracer Study adalah salah satu tahapan kegiatan yang yang dilakukan dalam rangka mengetahui kompetensi lulusan dan kebutuhan pasar. Tracer Study dapat mengukur dan melacak kinerja lulusan sehingga dalam hal ini dapat diperoleh indikator yang jelas tentang profil lulusan. Profil lulusan ini setidaknya meliputi keberhasilan para lulusan setelah berada di lapangan/dunia kerja yang telah memperoleh pekerjaan dan yang belum memperoleh pekerjaan, jenis pekerjaan yang digelutinya, mobilitas kerja, perkembangan karir, kepuasan kerja, imbalan atau nilai ekonomi yang telah mereka peroleh.

Jurnal Edueksos Vol IX, No. 2, Desember 2020

The journal of social and economics education 
Pelacakan alumni yang dilakukan secara manual yaitu dengan cara menghubungi satu persatu menggunakan telepon mengakibatkan biaya lebih mahal, tidak efektif dan efisien. Website tracer study sangat dibutuhkan untuk pengumpulan data alumni sehingga universitas mendapatkan data yang selalu up todate tentang pekerjaan alumni, mempermudah pengambilan keputusan, menghemat biaya dan lebih efektif dalam pelaksanaan pengumpulan data alumni. Metode pengembangan sistem ini pada Universitas Prof. DR. Hazairin, SH Bengkulu menggunakan metode waterfall meliputi tahap perencanaan, analisis, perancangan, implementasi, dan pengujian (Diana, 2017). Strategi untuk merancang sistem informasi alumni harus mempertimbangkan aspek-aspek database, jaringan internet, hosting, coding, dan desain sehingga tampilan sistem informasi dapat menarik stakeholders (Nursubiyantoro, 2016).

Sistem aplikasi tracer study Universitas Madura dibangun berbasis aplikasi web dan mendukung database postgreSQL memberikan kemudahan bagi alumni untuk mengisi kuisioner dan profil dari website yang disediakan (Rachmatullah, 2016). Sedangkan informasi yang disajikan dalam Tracer Study Universitas Bung Hatta berbasis web ini berbentuk matrik atau tabel. Program ini dibuat dengan bahasa pemrograman $p h p$ dan $M y S Q L$ dengan menggunakan bootstrap sebagai tool CMS (Suryani, 2015). Pengembangan sistem informasi tracer study berbasis web juga sudah dikembangkan di SMA Suluh Jakarta Selatan dengan metode RUP (Rational Unified Process) (Juwita, 2019).

Tracer study yang dilakukan oleh Fajaryati terhadap alumni Prodi Pendidikan Teknik Informatika UNY diperoleh hasil yaitu (1) sebagian besar alumni Prodi Pendidikan Teknik Informatika mendapatkan pekerjaan dengan masa tunggu kurang dari 6 bulan yaitu sebanyak 88\%; (2) alumni memberikan penilaian baik terhadap penyelenggaraan dan mutu layanan dari persepsi semua aspek, namun dibutuhkan peningkatan dari segi SDM maupun fasilitas sarana dan prasarana; (3) pengguna alumni menilai bahwa kompetensi lulusan sangat baik dari aspek integritas, profesionalisme, penggunaan TI, komunikasi, kerjasama tim, dan pengembangan diri, namun masih kurang dalam penggunaan bahasa, khususnya bahasa Inggris (Fajaryati et al., 2015). 
Hasil penelitian yang dilakukan oleh Sriyono terhadap lulusan Prodi Pendidikan Geografi UNNES 2009 adalah 1) rerata waktu tunggu para lulusan dalam memperoleh pekerjaan setelah lulus sebesar 6 bulan; 2) tingkat keterserapan lulusan di lapangan kerja sebesar 96\%; 3) sebaran atau distribusi jenis pekerjaan yang diperoleh para lulusan sebagian besar di bidang pendidikan yakni tenaga pendidik; 4) materi perkuliahan yang diberikan kepada mahasiswa yang termaktub di dalam kurikulum prodi dirasakan oleh para lulusan masih relevan dengan bidang keahlian di lapangan kerja mereka dan masih sinergi dengan kurikulum di sekolah sebagai lapangan kerja (Sriyono, 2009).

Sedangkan hasil penelitian Mariana terhadap alumni mahasiswa Program Studi Sistem Informasi UNISBANK Semarang menunjukkan bahwa: 1) kompetensi hard skill maupun soft skill lulusan secara keseluruhan adalah baik; 2) kepuasan alumni terhadap layanan yang diberikan program studi sebesar $56.4 \%$ menyatakan puas, dan terhadap kompetensi sebesar 48,7\% menyatakan puas; 3) sebanyak 76,9\% alumni menyatakan mampu bersaing dengan lulusan perguruan tinggi lain, 4) pengalaman belajar di laboratorium, masyarakat, magang, organisasi kemahasiswaan dan pergaulan kampus mempunyai peran yg sangat penting dalam mendukung kompetensi para lulusan (Mariana, Rejeki, \& Razaq, 2015).

Tidak jauh berbeda dengan hasil penelitian terhadap lulusan prodi Pendidikan Fisika Universitas Sarjanawiyata Tamansiswa (UST) Yogyakarta yaitu (1) sebesar $92 \%$ lulusan bekerja sebagai guru, baik sebagai guru IPA di SMP maupun guru Fisika di SMA (2) sebanyak 75\% memperoleh gaji > 1 juta rupiah (3) tingkat kesesuaian pendidikan yang diperoleh dengan jenis pekerjaan, bagi alumni yang bekerja menjadi guru Fisika di SMA sederajat $85 \%$ bermanfaat dan mendukung pekerjaan, untuk guru IPA sebesar 60\% mendukung pekerjaan dan untuk pekerjaan lainnya hanya 30\% mendukung pekerjaan (4) sebesar 96\% mendapatkan pekerjaan <6 bulan (Prihatni, 2016).

Tracer study memiliki peran penting dalam menjaring informasi dari alumni sebagai bahan evaluasi dan pengembangan perguruan tinggi ke arah yang lebih baik. Alumni membawa manfaat akademik maupun bidang pragmatis, seperti 
pemutakhiran kurikulum berbasis relevansi dengan kebutuhan pasar/ dunia kerja, dan pemanfaatan alumni sebagai dosen tamu, kegiatan seminar/ training dan lainlain (Zulhimma, 2015).

Berangkat dari hal tersebut, tracer study penting dilakukan karena urgensitasnya seiring dengan adanya berbagai inovasi program yang kini ingin diterapkan oleh IAIN Syekh Nurjati Cirebon dalam rangka untuk mengetahui implikasi pengembangan kurikulum yang diterapkan terhadap kualitas lulusan yang dihasilkan. Jurusan Tadris IPS Fakultas Ilmu Tarbiyah dan Keguruan IAIN Syekh Nurjati Cirebon menjadi salah satu jurusan yang dijadikan objek kajian dalam penelitian ini. Sebagai salah satu Jurusan yang bergerak dan memproduksi para lulusan yang kompeten di bidang profesionalisme kependidikan dan pengajaran, Tadris IPS diharapkan dapat menghasilkan lulusan yang dapat diserap dunia kerja dengan kompetensi pendidikan yang diperolehnya. Meskipun demikian, tidak menutup kemungkinan mereka dapat bekerja di luar bidang pendidikan. Hal ini sesuai dengan SK MENKOKESRA No. B192/MENKO/KESRA/VIII/1993 tentang penyaluran lulusan LPTK (Lembaga Pendidik Tenaga Kependidikan) untuk bekerja di luar Departemen Pendidikan dan Kebudayaan.

Terkait dengan hal tersebut di atas, sampai saat ini belum ada data akurat tentang keberadaan lulusan Tadris IPS khususnya dari tahun 2015 hingga tahun 2018, sementara data tentang keberadaan lulusan ini sangat diperlukan khususnya dalam melihat tingkat keberhasilan program dan kurikulum yang diterapkan Tadris IPS sebagai jurusan yang memiliki tugas untuk menyiapkan SDM yang mumpuni dalam hal kependidikan dan pengajaran. Dengan alasan ini, diperlukan mengadakan riset penelusuran alumni (tracer study) di Jurusan Tadris IPS Fakultas Ilmu Tarbiyah dan Keguruan IAIN Syekh Nurjati Cirebon.

Adapun tujuan dari penelitian ini adalah untuk memperoleh data aktual mengenai (1) Kesesuaian pekerjaan alumni Jurusan Tadris IPS IAIN Syekh Nurjati Cirebon tahun 2015-2018; (2) Relevansi kurikulum Jurusan Tadris IPS IAIN Syekh Nurjati Cirebon; (3) Keberadaan himpunan alumni Jurusan Tadris IPS IAIN Syekh Nurjati Cirebon. 


\section{B. METODE PENELITIAN}

Penelitian ini menggunakan pendekatan metode kuantitatif deskriptif. Penelitian kuantitatif menuntut variabel yang diteliti dapat diukur dan dinyatakan dalam angka. Penggunaan angka memungkinkan ketepatan yang lebih baik dalam menyajikan hasil penelitian. Pertanyaan yang dijawab responden pada penelitian kuantitatif juga bersifat tetap, dimana semua responden akan menjawab pertanyaan yang sama (Morissan, 2016).

Populasi diartikan sebagai wilayah generalisasi dari hasil penelitian yang dilakukan terhadap objek atau subjek penelitian. Objek penelitian adalah sesuatu yang menjadi bahan perhatian penelitian, sedangkan subjek penelitian adalah sumber dari objek penelitian tersebut (Jaya, 2019). Subjek penelitian adalah para alumni Tadris IPS Fakultas Ilmu Tarbiyah dan Keguruan IAIN Syekh Nurjati Cirebon yang lulus tahun 2015-2018 sebanyak 280 orang. Waktu penelitian dilakukan selama empat bulan, yaitu sejak selama empat bulan, yaitu Juli sampai Oktober 2018.

Data yang digunakan dalam penelitian ini adalah data primer yang diperoleh dengan cara mengirimkan angket (google form) kepada responden. Instrumen angket berisi daftar pernyataan yang merupakan indikator dari kesesuaian pekerjaan alumni, relevansi kurikulum dan keberadaan himpunan alumni. Jawaban angket merupakan kombinasi dari jawaban pilihan, jawaban singkat dan jawaban panjang.

Penelusuran data alumni diperoleh dari arsip jurusan, kemudian peneliti menghubungi nomor kontak atau email. Selama periode penelitian, angket yang terisi sebanyak 51 orang $(18,21 \%)$. Data penelitian yang berhasil dikumpulkan tersebut kemudian dianalisis secara kuantitatif dengan teknik analisis prosentase serta menyajikannya dalam bentuk tabel maupun grafik.

Statistik deskriptif bertujuan untuk mendeskripsikan atau memberikan gambaran terhadap objek yang diteliti melalui penyajian tabel, grafik, atau diagram. Bisa juga dengan cara menghitung nilai rata-rata, median, modus, kuartil, standar deviasi dll (Sujarweni, 2015). 
Skala prosentase digunakan untuk menganalisis jawaban angket dari responden. Rumus :

$$
\text { Skala Prosentase }=\frac{\text { Total jawaban angket yang diperolel h }}{\text { Total maksimal jowaban angliet }} \mathrm{x} 100 \%
$$

Tabel 1. Interpretasi Skala Rekapitulasi Hasil Angket

\begin{tabular}{cc}
\hline Prosentase & Interpretasi \\
\hline $100 \%$ & Seluruhnya \\
$90 \%-99 \%$ & Hampir Seluruhnya \\
$60 \%-89 \%$ & Sebagian Besar \\
$51 \%-59 \%$ & Lebih dari Setengahnya \\
$50 \%$ & Setengahnya \\
$40 \%-49 \%$ & Hampir Setengahnya \\
$20 \%-39 \%$ & Sebagian Kecil \\
$1 \%-19 \%$ & Sedikit Sekali \\
$0 \%$ & Tidak sama Sekali \\
\hline
\end{tabular}

(Arikunto, 2008)

\section{HASIL DAN PEMBAHASAN}

\section{Karakteristik Data Responden}

Reponden penelitian berasal dari mahasiswa Jurusan Tadris IPS tahun masuk 2010-2014 yang lulus tahun 2015-2018 berjumlah 51 orang. Berdasarkan jenis kelamin, perempuan lebih banyak yakni $55 \%$ dan laki-laki $45 \%$. Sedangkan berdasarkan asal sekolah, maka responden yang berasal dari SMU lebih banyak yakni 55\%, diikuti MA 35\% dan SMK 10\%. Lihat tabel 2.

Tabel 2. Data Responden Berdasarkan Jenis Kelamin dan Asal Sekolah

\begin{tabular}{ccccc}
\hline \multicolumn{5}{c}{ Asal Sekolah } \\
JK & SMU & SMK & MA & Jumlah \\
Laki-laki & 11 & 0 & 11 & 22 \\
Perempuan & 15 & 5 & 9 & 29 \\
Total & $\mathbf{2 6}$ & $\mathbf{5}$ & $\mathbf{2 0}$ & $\mathbf{5 1}$ \\
\hline
\end{tabular}

Ilmu-ilmu sosial cenderung lebih banyak diminati oleh perempuan, terlihat dari jumlah mahasiswi di jurusan Tadris IPS lebih banyak dibandingkan mahasiswa. Sebagai jurusan yang bernaung di bawah Kementerian Agama, Jurusan Tadris IPS menerima mahasiswa yang berasal dari Madrasah Aliyah 
(MA), di samping Sekolah Menengah Umum (SMU) dan Sekolah Menengah Kejuruan (SMK).

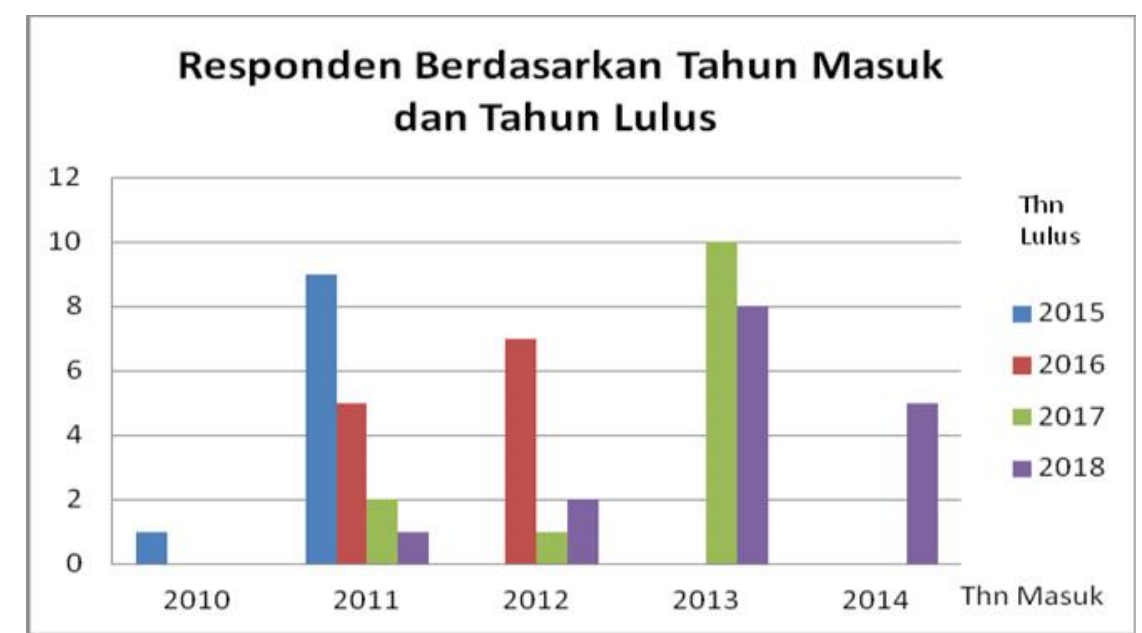

\section{Gambar 1. Distribusi Responden Berdasarkan Tahun Masuk dan Tahun Lulus}

Berdasarkan gambar 1, responden paling banyak berasal dari mahasiswa tahun masuk 2013 lulus tahun 2017 sebesar 10 orang, dan paling sedikit adalah tahun masuk 2010 lulus tahun 2015, tahun masuk 2011 lulus tahun 2018, serta tahun masuk 2012 lulus tahun 2017 masing-masing 1 orang. Dari data tahun masuk dan tahun lulus ini dapat diperoleh masa studi responden, dimana masa studi 4 tahun adalah masa studi terbanyak dari responden sebesar 22 orang, sedangkan masa studi terlama 6,5 tahun (13 semester) sebanyak 1 orang. Distribusi responden berdasarkan masa studi ini selengkapnya dapat dilihat pada gambar 2 .

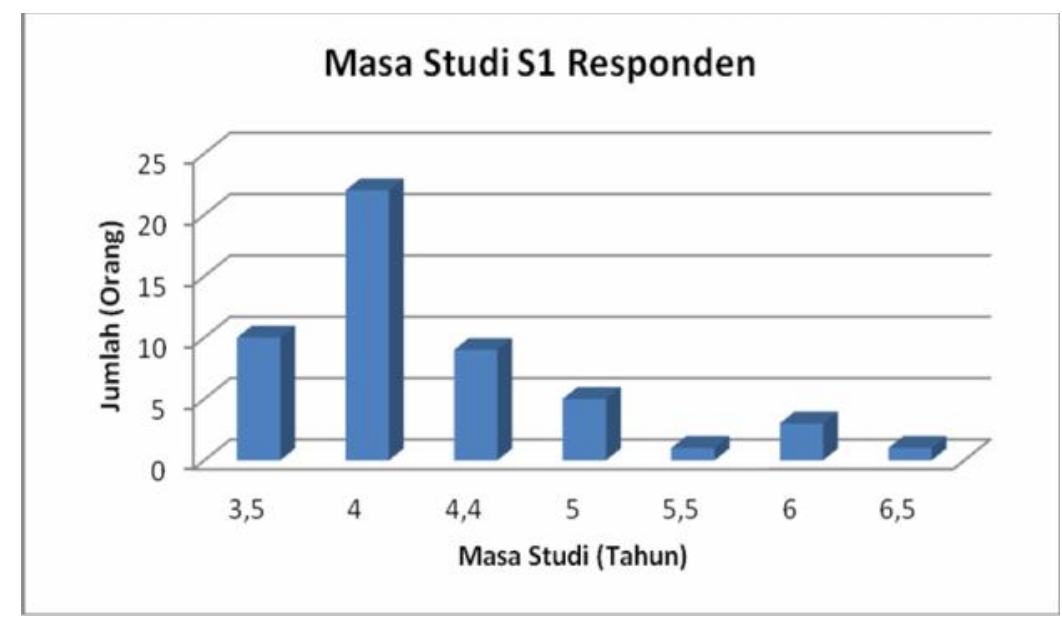

Gambar 2. Distribusi Masa Studi Responden 
Jurusan Tadris IPS masih memperkenankan mahasiswa menyelesaikan studi maksimal 14 semester (7 tahun) tahun masuk 2011. Mulai tahun masuk 2012, mahasiswa wajib menyelesaikan studi maksimal 12 semester (6 tahun).

\section{Kesesuaian Pekerjaan Alumni}

Setelah lulus menjadi sarjana pendidikan, alumni Tadris IPS hampir seluruhnya bekerja (90\%), sisanya melanjutkan kuliah ke jenjang S2 (4\%), dan menganggur $(6 \%)$. Lihat gambar 3.

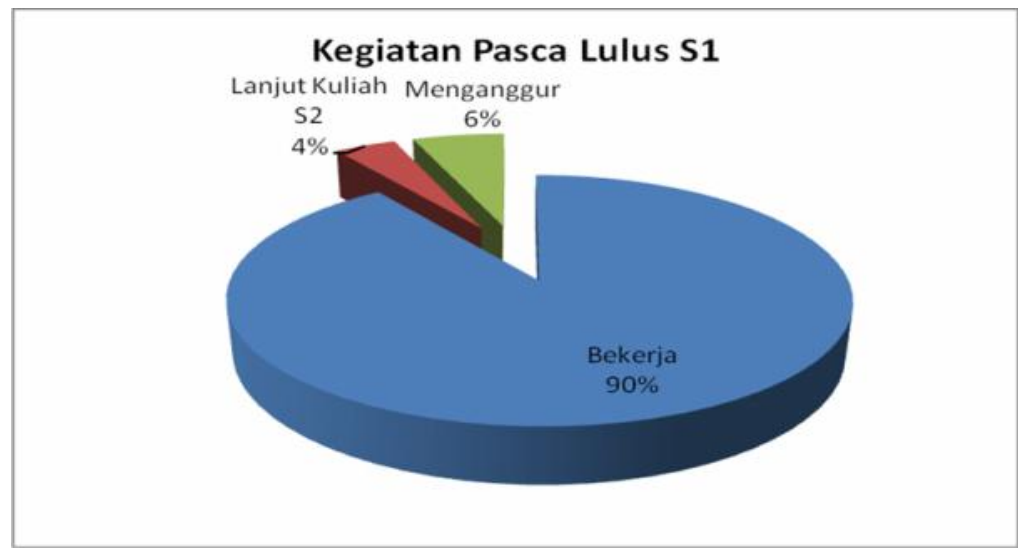

Gambar 3. Kegiatan Alumni Jurusan Tadris IPS

Waktu tunggu alumni untuk mendapatkan pekerjaan pertama setelah mereka lulus, paling cepat 1 bulan dan paling lama 18 bulan. Namun, beberapa dari mereka sudah bekerja sambil kuliah dan menyelesaikan skripsinya. Adapun penyebaran waktu tunggu alumni mendpatkan pekerjaan pertama kali dapat dilihat pada gambar 4 .

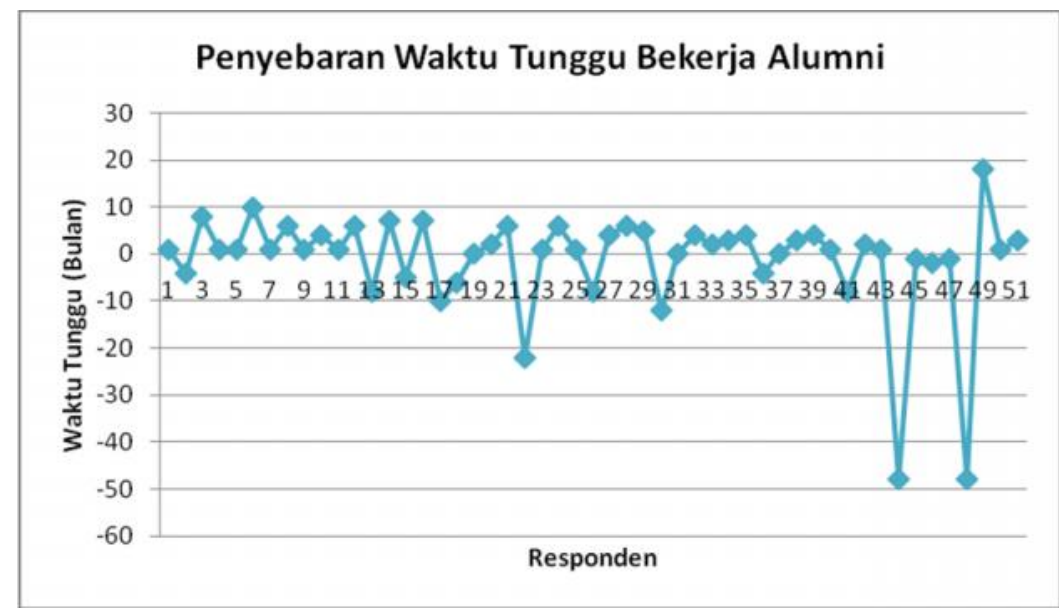

Gambar 4. Penyebaran Waktu Tunggu Pekerjaan Pertama Alumni 
Kalau dilihat dari jenis pekerjaannya, maka alumni pertama kali bekerja sebagian besar sebagai guru (63\%), sisanya sebagai staff swasta (21\%), staff pemerintahan $(10 \%)$, dan wirausaha $(6 \%)$. Dari pekerjaan ini, rata-rata gaji pertama alumni sebesar 958.000.,- per bulan, paling tinggi sebesar Rp 7.000.000,-, dan paling rendah $\mathrm{Rp}$ 100.000,-. Penghasilan terbesar dikarenakan alumni berwirausaha, dan yang paling kecil bekerja sebagai guru honorer dan admin.

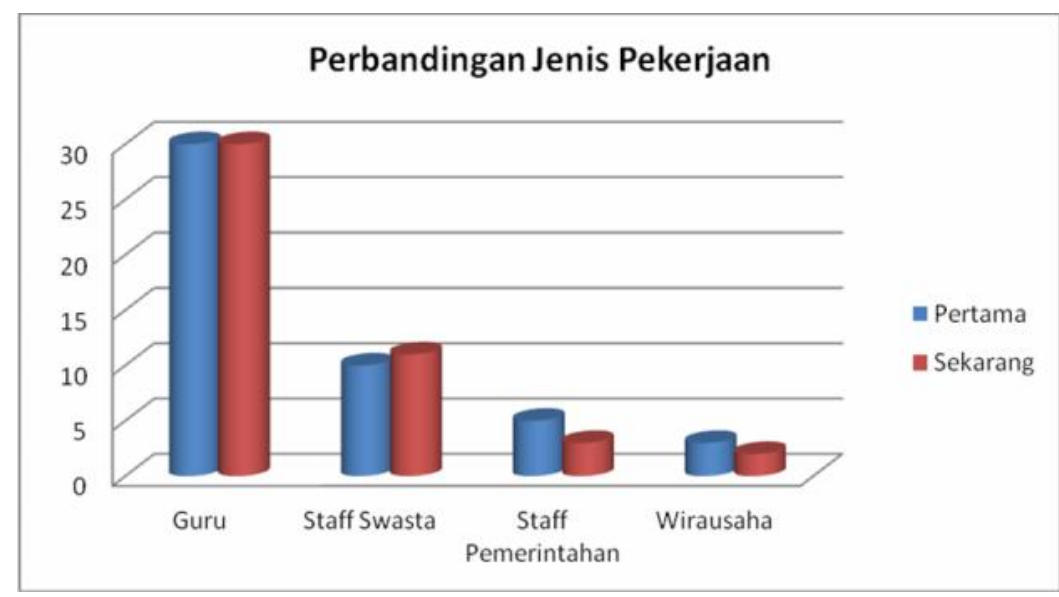

\section{Gambar 5. Perbandingan Jenis Pekerjaan Alumni Tadris IPS Pertama dan Sekarang}

Apabila dibandingkan dengan pekerjaan alumni sekarang, maka profesi guru masih tetap dominan dibandingkan pekerjaan lainnya yaitu staff swasta, staff pemerintahan maupun wirausaha (Lihat gambar 5). Namun, penghasilan rata-rata alumni meningkat menjadi Rp 1.525.000,-, per bulan, tertinggi Rp 7.000.000,- dan terendah Rp 200.000,-. Penghasilan terbesar dikarenakan alumni bekerja sebagai wirausaha dan TKW, dan yang paling kecil bekerja sebagai guru honorer. Dari gambar 6, terlihat bahwa hampir seluruh alumni mendapatkan penghasilan dari pekerjaan sekarang yang lebih tinggi dibandingkan dengan penghasilan pekerjaan pertama kali. Hal ini karena alumni sekarang semakin mapan dalam bekerja, baik pada tempat yang sama maupun berubah ke pekerjaan yang lebih baik. 


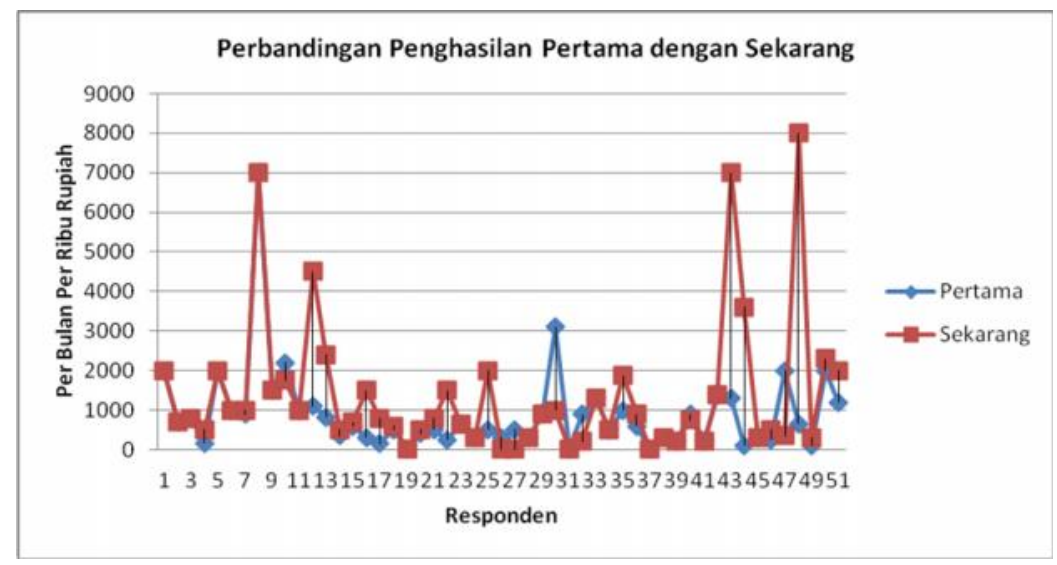

\section{Gambar 6. Perbandingan Penghasilan Alumni Pekerjaan Pertama dan Sekarang}

Sebagai sarjana pendidikan, tentulah para alumni berpendapat bahawa pekerjaan yang sesuai dengan cita-citanya adalah sebagai guru/dosen PNS. Namun, ada juga alumni yang mengatakan bahwa pekerjaannya masih belum sesuai dengan cita-citanya karena mereka ada yang menginginkan bekerja sebagai pengusaha, sekretaris desa, dan manajer perkantoran. Data kesesuaian pekerjaan sekarang dengan cita-cita, diperoleh lebih dari setengahnya (55\%) sesuai dan sisanya $45 \%$ tidak sesuai (Gambar 7).

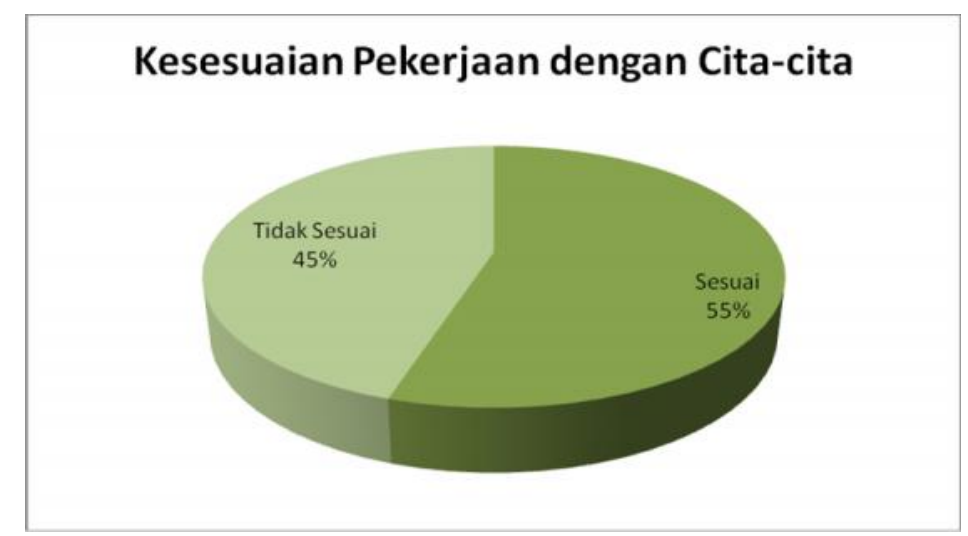

\section{Gambar 7. Kesesuaian Pekerjaan Alumni Sekarang dengan Cita-cita}

Ketidaksesuaian pekerjaan alumni sekarang disebabkan karena sulitnya mendapatkan pekerjaan yang sesuai denga latar belakang pendidikan IPS sebagai guru IPS di SMP/MTs. Sedangkan kelebihan alumni Jurusan Tadris IPS mampu bekerja di luar pendidikan, seperti perbankan, perusahaan swasta maupun 
pemerintah karena kemampuan mereka menguasai ilmu komputer, bahasa, agama, serta lebih mudah beradaptasi, dan berinteraksi dengan masyarakat.

\section{Relevansi Kurikulum Jurusan Tadris IPS}

Pekerjaan alumni Jurusan Tadris IPS berbeda-beda, di samping bekerja di bidang pendidikan, ada juga yang bekerja di perusahaan swasta, pemerintahan, dan wirausaha. Oleh karena itu, tentulah dibutuhkan ilmu yang berbeda-beda pula.

Gambar 8 memperlihatkan bahwa lebih dari setengahnya (57\%) alumni menjawab bahwa kurikulum Jurusan Tadris IPS cukup sesuai dengan ilmu pengetahuan yang dibutuhkan pekerjaan, 33\% sesuai, $8 \%$ kurang sesuai dan $2 \%$ tidak sesuai. Ilmu yang sesuai dengan pekerjaan adalah ilmu pendidikan, ilmuilmu sosial, dan ilmu teknologi informasi komunikasi.

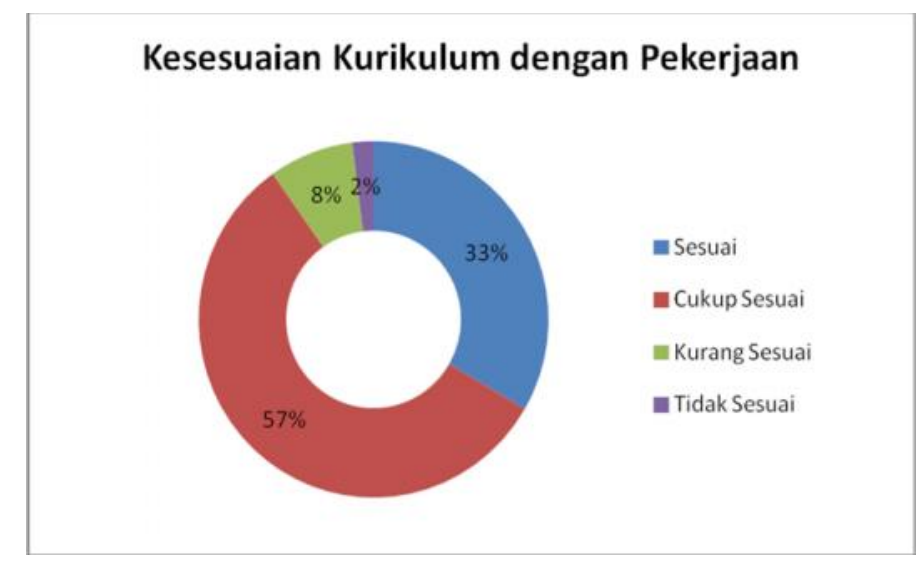

\section{Gambar 8. Kesesuaian Kurikulum Jurusan Tadris IPS dengan Pekerjaan Alumni}

Apabila dilihat satu per satu, maka mata kuliah Kapita Selekta IPS adalah mata kuliah yang paling relevan dengan pekerjaan. Hal ini dikarenakan mata kuliah ini membahas materi IPS yang akan diajarkan di SMP/MTs, dengan mengingat bahwa pekerjaan alumni sebagai guru IPS di SMP/MTs. Selain itu, mata kuliah lainnya yang relevan adalah Sosiologi Pendidikan, Etika Profesi Keguruan, Pengembangan Kurikulum, Microteaching, Perencanaan Pembelajaran, Statistik Dasar, Penelitian Tindakan Kelas, Teknologi Informasi dalam Pembelajaran, Model dan Media Pembelajaran, Pengelolaan Pembelajaran, Pembelajaran Berbasis Lingkungan Hidup, Pancasila dan Kewarganegaraan, Sejarah, Psikologi Pendidikan, Psikologi Perkembangan, dan Bimbingan Konseling. 
Bagi alumni yang bekerja di luar pendidikan dan wirausaha maka mata kuliah yang relevan adalah Bahasa Inggris, Aplikasi Komputer, Akuntansi, Dasar Ilmu Politik, Kependudukan, Pengembangan Keterampilan Membuat Peta, Kewirausahaan, Matematika Ekonomi, Modal Sosial, Kajian Isu Global, Perkembangan Masyarakat Global, Pengembangan Keterampilan Sosial, Studi Masyarakat Indonesia, Produksi Distribusi Konsumsi, Manusia Tempat Lingkungan, Kajian Kearifan Lokal, dan Kajian Konflik Sosial.

Menurut alumni, ada beberapa mata kuliah yang perlu ditambahkan guna menunjang pekerjaan yaitu IPS untuk SMU/SMK secara terpisah (Geografi, Sejarah, Sosiologi, Ekonomi), Ilmu komputer (seperti MS Excell), Akuntansi Keuangan, Manajemen Bisnis, Pendidikan Ilmu Politik, serta Manajemen/Administrasi Pendidikan.

\section{Keberadaan Himpunan Alumni}

Himpunan alumni sebagai tempat perkumpulan para alumni, mutlak diperlukan bagi setiap jurusan/program studi. Namun, menurut sebagian besar responden (63\%) menyatakan belum ada himpunan alumni Jurusan Tadris IPS IAIN Syekh Nurjati Cirebon, 19\% sudah, dan 18\% tidak tahu (Lihat gambar 9).

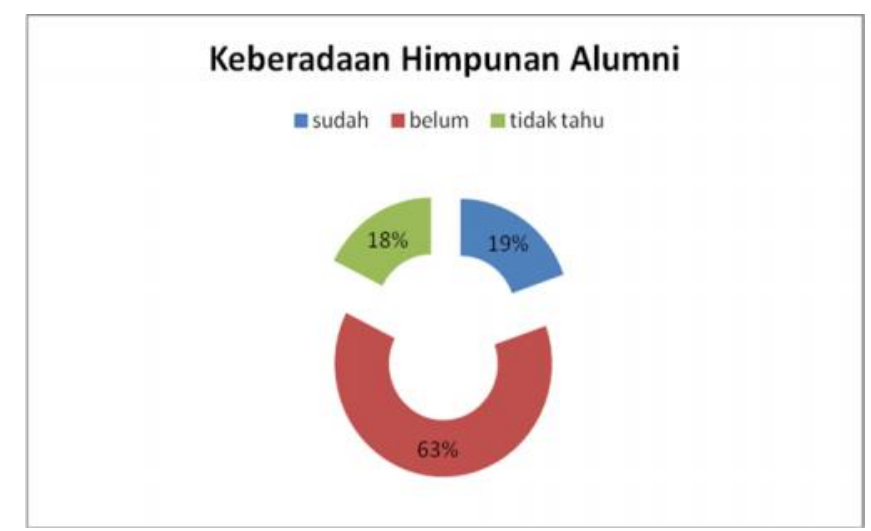

\section{Gambar 9. Informasi Keberadaan Himpunan Alumni Jurusan Tadris IPS}

Menurut alumni, nama himpunan alumni bermacam-macam. Ada HIMASOS, Pegasos, Sleeim, Lajang, yang ternyata itu adalah nama grup kelas masing-masing. HIMASOS (Himpunan Mahasiswa Sosial) sebenarnya adalah nama himpunan mahasiswa Jurusan Tadris IPS yang masih aktif menjadi 
mahasiswa. Namun, alumni kadang-kadang masih menggunakan nama HIMASOS dalam kegiatannya.

Hambatan sulitnya terbentuk himpunan alumni adalah karena kurangnya komunikasi antar alumni, kesibukan masing-masing alumni, kehilangan nomor kontak, tidak ada yang memeloporinya, kurang sosialisasi dan koordinasi, individualistis, jarak yang jauh, dan kurangnya minat. Komunikasi menjadi faktor penting bagi terbentuknya himpunan alumni, sehingga nomor kontak diusahakan tidak berubah.

Salah satu upaya yang dapat dilakukan adalah dengan mengadakan acara reuni. Melalui acara ini, diharapkan terjalin silaturahmi dan komunikasi yang baik antar alumni, sambil mengumpulkan nomor kontak. Grup yang baru terbentuk adalah grup kelas di sosial media, juga bisa menjadi awal rekonstruksi terbentuknya himpunan alumni yang lebih legal dan luas.

Kegiatan yang sering dilakukan oleh para alumni adalah kegiatan keagamaan (seperti buka puasa bersama, halal bi halal), kegiatan bakti sosial (seperti peduli bencana), dan pelatihan character building/leadership development. Melalui kegiatan ini seperti yang terlihat pada gambar 10, diharapkan bermanfaat bagi para alumni yaitu lebih dari setengahnya mempererat tali silaturahmi $(56 \%)$, berbagi informasi (25\%), forum diskusi (15\%), dan menambah jaringan (4\%).

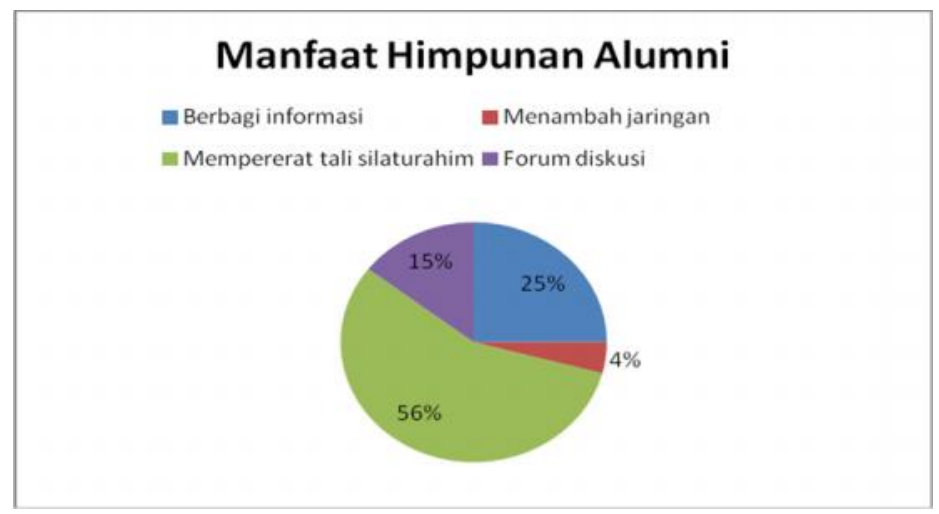

Gambar 10. Manfaat Himpunan Alumni

\section{KESIMPULAN}

Rata-rata waktu tunggu alumni untuk mendapatkan pekerjaan pertama kali adalah 3,96 bulan. Jenis pekerjaan alumni yang pertama sebagian besar sebagai guru, sisanya sebagai staff swasta, staff pemerintahan dan wirausaha. Dari 
pekerjaan ini, rata-rata gaji pertama alumni sebesar Rp 958.000.,- per bulan. Dari pekerjaan alumni tersebut lebih dari setengahnya menyatakan sudah sesuai.

Dalam hal kurikulum, lebih dari setengahnya alumni menyatakan bahwa kurikulum Jurusan Tadris IPS cukup sesuai dengan ilmu pengetahuan yang dibutuhkan pekerjaan. Ilmu-ilmu tersebut dapat dikelompokkan menjadi ilmu-ilmu sosial, ilmu-ilmu pendidikan, dan ilmu teknologi informasi komunikasi.

Saat ini, keberadaan himpunan alumni Jurusan Tadris IPS masih sebatas grup kelas di media sosial. Kegiatan yang biasa dilakukan adalah kegiatan keagamaan, bakti sosial, dan pelatihan character building. Melalui kegiatan tersebut, antar alumni bisa saling silaturahmi, berbagi informasi, diskusi santai dan menambah jaringan.

Untuk saran agar jurusan Tadris IPS harus lebih tanggap akan kebutuhan ilmu-ilmu yang diperlukan guna menunjang dunia kerja para lulusan, sehingga up date kurikulum harus sering dilakukan. Perlunya digerakkan kembali himpunan alumni secara formal dan terpusat, sehingga antar alumni dapat terjalin kerjasama yang lebih erat, serta alumni lebih berperan aktif mendukung kegiatan kampus.

\section{DAFTAR PUSTAKA}

Arikunto, S. (2008). Prosedur Penelitian Suatu Pendekatan Praktik. Jakarta: Rineka Cipta.

Chandra, R., \& Ruhama, S. (2014). Pengembangan Sistem E-Tracer Study pada Perguruan Tinggi. KNSI, 394-398. Makassar: STMIK Dipanegara.

Diana, E. dan A. (2017). Analisis dan Perancangan Sistem Informasi Tracer Study Berbasis Web. Mediasisvo, 11(2), 817-829.

Fajaryati, N., Sukardiyono, T., Dwi, A., Utami, W., Pambudi, S., \& Destiana, B. (2015). Studi Penelusuran (Tracer Study) terhadap Alumni Program Pendidikan Teknik Informatika Jurusan Pendidikan Teknik Elektronika Fakultas Teknik Universitas Negeri Yogyakarta. Elinvo, 1(1), 44-48.

Jaya, I. (2019). Penerapan Statistik untuk Penelitian Pendidikan. Jakarta: Prenada Media Group.

Juwita, M. I. S. A. W. dan N. Y. S. (2019). Pengembangan Sistem Informasi Tracer Study Alumni Berbasis Web Menggunakan Metode RUP (Studi

Jurnal Edueksos Vol IX, No. 2, Desember 2020

The journal of social and economics education 
Kasus: SMA Suluh Jakarta Selatan). Jurnal Pengembangan Teknologi Informasi Dan Ilmu Komputer, 3(6), 5703-5710. Retrieved from jptiik.ub.ac.id

Mariana, N., Rejeki, R. S. A., \& Razaq, J. A. (2015). Tracer Studi Mahasiswa Program Studi Sistem Informasi Universitas STIKUBANK Semarang. Dinamika Informatika, 7(2), 75-84.

Morissan. (2016). Metode Penelitian Survei (4th ed.). Jakarta: Kencana.

Nursubiyantoro, E. dan P. (2016). Perancangan Sistem Penelusuran Alumni (Tracer Study) Berbasis Web. Jurnal OPSI, 9(2), 85-92.

Prihatni, Y. \& P. H. W. (2016). Tracer Study pada Lulusan Prodi Pendidikan Fisika. Sosiohumaniora, 2(2), 1-5.

Rachmatullah, S. dan I. G. (2016). Aplikasi Tracer Study Universitas Madura. Jurnal Insand Comtech, 1(2), 31-37.

Sriyono. (2009). Tracer Study Mahasiswa Lulusan Program Studi Pendidikan Geografi. Jurnal Geografi, 6(2), 99-110.

Sujarweni, V. W. (2015). SPSS untuk Penelitian (Florent, ed.). Yogyakarta: Pustaka Baru Press.

Suryani, K. dan K. (2015). Tracer Study Online Universitas Bung Hatta. Jurnal Edik Informatika, 2(1), 16-24.

Syaubari, Meilina, H., \& Adisalamun. (2015). Panduan Pelaksanaan Tracer Study. Aceh: Program Studi Magister Teknik Kimia Program Pascasarjana Universitas Syiah Kuala.

Zulhimma. (2015). Tracer Study Alumni dalam Meningkatkan Mutu Akademik di Fakultas Tarbiyah dan Ilmu Keguruan IAIN Dangsidempuan. Tazkir, 1(2), 92-107. 